\title{
CHARACTER EDUCATION RELATION WITH SPIRITUAL INTELLIGENCE IN ISLAMIC EDUCATION PERSPECTIVE
}

\author{
Etep Rohana \\ Program Studi Pendidikan Agama Islam \\ Fakultas Agama Islam Universitas Islam Nusantara Bandung \\ Email: eteprohana@uninus.ac.id
}

\begin{abstract}
This article tries to discuss about character education building in an Islamic education perspective. It is education that forms superior character and human character in terms of intellectual, emotional, and spiritual intelligence. The totality of these three bits of intelligence will shape humans. This article is written using a sociological approach with a descriptive type. The method used is library research. The findings obtained indicate that the concept of character education in Indonesia is education that emphasizes great values originating from Indonesian national culture in the context of fostering the personality of the young generation which includes three aspects, namely moral knowledge, moral attitude, and ethical behavior (decent acting). It is following the objectives of Islamic education, which provides for three physical, spiritual, and reason aspects. Therefore, building complete human resources, in essence, is the development of character and superior human character from the intellectual, emotional, and spiritual side that can actualize the dimensions of intellectual, emotional, and spiritual intelligence holistically in the life.
\end{abstract}

Keywords: character education; intellectual intelligence, emotional intelligence; spiritual intelligence; complete man

\section{A. INTRODUCTION}

Character education (Nucci, Narvaez, \& Krettenauer, 2014) has a higher meaning than moral education (Nurdin, 2017). Character education (Sanderse, 2012) is not only related to rightwrong problems, but also how to instill habits about good things in life (Reksiana, 2018). With character education, students have a high awareness, and understanding, as well as care and commitment to apply virtue in daily life (Musfiroh \& Setiawan, 2019).

Character education is a national issue (Manasikana \& Anggraeni, 2018) which is the responsibility of higher education (Irhandayaningsih, 2013) as well as the responsibilities of parents and families (Rahim, 2013) when students are not in an educational or institutional environment (Bali, 2013). Character education is important in order to support the government's efforts to realize the mandate of the 1945 Constitution which educates all Indonesian citizens through education in other words to create educated human beings.

National education functions (Verger \& Novelli, 2012) to develop capabilities and shape dignified national character and civilization in order to educate the life of the nation (Omeri, 2015). National education aims to develop the potential of students to become human beings who believe and fear God Almighty, have noble character, are healthy, knowledgeable, capable, creative, independent, and become democratic and responsible citizens (Syarif, 2017). 
Character definition is equated with value education, moral education, religious education, or character education. This term is increasingly raised when various problems arise as a result of the failure of education in Indonesia (Wijaya \& Helaluddin, 2018). The term character comes from the Greek word charassain which means to carve. In simple terms, it can be interpreted that character education is a form of activity carved on stone which in its implementation is not easy / easy (Samrin, 2016).

One of the facts in the world of education that shows concern is that Indonesian education is not enough to succeed in producing a generation that excels in all aspects (Tulus, 2013), namely cognitive, affective and psychomotor. In fact, the amount of corruption committed by officials who have higher education levels, but has an attitude and character that is not much different from criminals, rapists, and robbers. It seems they have lost a conscience that is sincere, sincere and grateful that justifies any means to achieve its goals (McKay, 2009, p. 11). Their goals are different from the beliefs they adhere to. They are very easy to swear on "the Scriptures" and are ready to break them. It is true that this nation has never progressed because it has "resisted" the Supreme Lord (Muhdar HM, 2013).

The identity crisis that characterizes the nation's character (Hadisi, 2015) who was born from the world of education tends not to be confident to be himself. In these conditions the concepts of western education are difficult to avoid, tend to disguise local concepts and teachings even though they are believed to be conditions with moral values that need to be instilled in students as one way to shape the character of the nation (Aini, Ruslan, \& Ely, 2013).

Character education is here to give light after the darkness comes. Character education will "carve" on stone and the process of carving it takes a long time and process. So, character education must break down in every aspect of the life of the world of education so that it becomes a habitus to produce generations of people who have superior spiritual intelligence as a straight path to the science of education. To illustrate these things, this article was written.

\section{B. METHOD}

This article is written using library research. This is done by taking resources through the study of Islamic Education books related to Character Education and Spiritual Intelligence. The approach taken is a descriptive-narrative approach, which results in a complete description of the chosen theme.

\section{RESULT AND DISCUSSION}

\section{Character Education}

Character education is education to shape one's personality (Pesci, 2018, p. 246) through character education (Andayani, Yusuf, \& Hardjajani, 2011), the results of which are seen in a person's real actions, namely good and honest behavior, responsibility, respect for other people's rights, hard work, and so on, this can be attributed to destiny, namely introduction and affirmation or actualization of the results of the introduction (Anees \& Hambali, 2010, p. 99).

Muslim philosophers from the beginning have expressed the importance of character education. Ibnu Maskawih wrote a special book on morals and put forward the formulation 
of the main character of a human being. Likewise, Al-Ghazali (Dasoo, 2010, pp. 359-375), Ibn Sina (Gil'adi, 1992, p. 31), Al-Farabi (Parens, 2012, p. 42), and many other philosophers. Before the results of the study of Islamic scholars on the Qur'an and Al-Hadith showed that the nature of Islam is the moral and mental character (Nata, 1996, p. xiv).

Majid and Andayani stated that Socrates argues that the most basic purpose of education is to make someone become good and smart. Prophet Muhammad SAW also stressed that his main mission in educating humans is to strive for good character formation. Worldwide Western education figures such as Klipatrick, Lickona, Brooks, and Goble seemed to echo the echo voiced by Socrates and Muhammad Saw that morality, character or character is an unavoidable goal of the world of education. While Mardiatmadja called character education as the spirit of education in humanizing humans (Majid \& Andayani, 2012, p. 30).

Furthermore, Majid and Andayani stated that character education has several pillars, among others (Majid \& Andayani, 2012, pp. 31-36): First, moral knowing, as the first aspect has six elements, namely: (1) moral awareness; (2) knowing moral values; (3) perspective taking; (4) moral reasoning; (5) decision making; and (6) self-knowledge. Second, moral loving or moral feeling, is the strengthening of the emotional aspects of students to become human characters. This reinforcement is related to the forms of attitudes that must be felt by students, namely awareness of identity, namely: (1) self-esteem; (2) empathy; (3) loving the good; (4) self-control; and (5) humility. Third, moral doing / acting, as an outcome, will easily emerge from students after the two pillars above are realized. Moral acting shows the battle rather than the competencies possessed by students after going through the learning process. The abilities possessed by students are not only beneficial for themselves but are able to provide benefits to others who are around them.

According to Muin, there are six main pillars (character pillars) in humans that can be used to measure and assess their character and behavior in special matters. These six characters can be said to be the pillars of human character among them (Muin, 2011, p. 211):

a. Essence of respect; it is our attitude that is serious and solemn to others and ourselves. Respect is usually shown in a polite manner and also reciprocates with kindness, both in the form of attitudes and gifts. Whereas respect is also ordinary means being tolerant, open, and accepting differences while respecting the autonomy of others.

b. Responsibility; the attitude of responsibility shows whether the person has good character or not. People who run from responsibility are often disliked, meaning that it is a bad character

c. Citizenship; the character needed to build citizens' awareness includes various actions to realize the creation of civil society that respects individual rights.

d. Fireness (justice and honesty); justice can refer to the same aspects (sameness) or give the rights of others. It can also be based on what has been done: people who work hard will get better and more meaning that there are aspects that must be seen when we understand the value of justice.

e. Caring (caring and willingness to share); concern is the glue of society. Concern is the nature that makes the culprit feel what others feel, knowing how it feels to be someone else, sometimes shown by the act of giving or engaging with other people. 
f. Tristworhiness (trust); the beliefs regarding several elements of character include; integrity, is the personality and character that unites what is said and done; honesty, what is said is true according to reality; keeping promises, what was said to be done, will really be done; loyalty, an attitude that maintains a relationship with action to show good relationships, not only giving, but also receiving positive things for the relationship to be established.

\section{Character Education in Islamic Education Perspective}

The emergence of character education gives its own color to the world of education, especially in Indonesia, although in reality character education has existed along with the birth of the Islamic education system because character education is a spirit rather than Islamic education itself. Islamic education is a system. The traditional definition states that a system is a set of components or elemental elements that interact to achieve a goal (Ramaliyus, 2010, p. 19).

Educational activities in the outline can be divided into three: (1) educational activities by themselves, (2) environmental education activities, and (3) educational activities by others (Tafsir, 2013, p. 36). Muhammad Fadhil al-Jamali as quoted by Mujib and Mudzakir defines Islamic education by: "efforts to develop, encourage, and invite people to be more advanced based on high values and noble life, so that a more perfect person is formed, both those who relating to reason, feelings and actions."(Mujib \& Mudzakir, 2006, p. 26).

It can be concluded that humans are educated to have good character in various fields. Not only to God but also to fellow beings who are on this earth..

\section{Spiritual Intelligence}

Spiritual intelligence is rooted in the philosophy of spiritualism, namely the flow which states that the subject of reality (foundation of relity) is spirit; the soul of the world which encompasses the universe in all its levels of activity; as a cause of its activities; orders and guidance (instructions); and act as a complete and rational explanation (Angeles, 1981, p. 273).

Etymologically spiritual intelligence consists of the words intelligence and spiritual. Intelligence in English is referred to as intelligence and in Arabic is zakā which means understanding, speed and perfection of something (Mujib \& Mudzakir, 2002, p. 318). It can also be said that the notion of intelligence is a monotheistic mindset, integralistic and principled only because of God (Agustian, 2002, p. 57). While spiritual comes from the word "spirit" which means soul, mental, and religious. In the dictionary of spiritual psychology (Anshori, 1995, p. 653) it is interpreted as an assumption regarding trasendental values (Darmadi, 2018, p. 15).

Furthermore, Danah Zohar and lan Marshall mention the uses of spiritual intelligence (Zohar \& Marshall, 2007, pp. 12-13) for: (1). Making us become human beings now and giving them the potential to continue to grow. (2). Become more creative. We present it when we want us to become lues, broad-minded, and spontaneous in creative ways. (3). Facing the 
problem of extensibility is when we are personally trapped by habits and worries, and our past due to sadness. Because with spiritual intelligence we are aware that we have an external problem and make us overcome it or at least we can make peace with the problem. (4). Spiritual intelligence can be used in crisis problems that make us feel as if we lose our order. With spiritual intelligence our conscience guides a more correct path. (5). We also have the right religious ability, without having to be fanatical and closed to life which is actually very diverse. (6). Spiritual intelligence allows us to bridge or unite personal and interpersonal things, between ourselves and others, so we will be aware of other people's integrity and our integrity. (7). Spiritual intelligence is also used to achieve more complete personal maturity because we do have the potential for it. Also because spiritual intelligence makes us aware of meaning and principles so that the ego will be numbered two, and we live based on eternal principles. (8). Using spiritual intelligence in dealing with choices and reality that is sure to come and we have to face any form. Good or bad evil or in all suffering that suddenly comes without our expectations.

\section{Relationship of Character Education to Spiritual Intelligence in the Perspective of Islamic Education}

Character education is easily accepted in Indonesia, especially by Muslim thinkers, not because of new concepts or theories, but because character education is implicitly existing in the concept of Islamic education that has been applied in Indonesia. Character education as if strengthening the Islamic education system is even appropriate if character education is a spirit rather than Islamic education. Islamic education is essentially an activity to shape students into human beings with character or values, have noble character so that they become human beings who are supported by God (Fathurrochman \& Apriani, 2017).

In Islamic education, students are the most important subject. As subjects, they should have a strong desire and have enthusiasm that will not be swayed by the temptations of satan and any worldly lust. Their enthusiasm is one of the factors that will lead him to achieve what he aspires to and lead them to the goals outlined earlier (Frimayanti, 2015).

With Islamic education, students will actually be formulated to become human beings with character and noble values. But with the emergence of the concept of character education more clearly about the character that must be possessed by a student after the process of teaching and learning activities carried out (Ainissyifa, 2014). Even in making the Learning Implementation Plan, after the emergence of character education in our country, the characters or values that must be achieved by students in each meeting must be clearly stated.

Character education formulates the values that must be possessed by students after completing the learning process in the classroom. The values or character that students must have at each meeting are adjusted to the learning material at that time. In essence in Islamic education these values are the main goal after learning activities in the classroom are conducted. Therefore, what is the basis of Islamic education is the foundation in establishing the concept of character education as well. It can be seen from the values or character formulated that it does not conflict with the basis or source of Islamic education, namely Al-Qur'an, Al-Sunnah and ljtihad (Syam, 2016). 
The basic characters formulated well by Indonesia Heritage foundation include: love for Allah and the universe and its contents, responsibility for discipline and independence, honesty, respect and courtesy, compassion, caring, and cooperation, confidence, creativity, hard work, and never give up, justice and leadership, kind and humble, tolerance, love of peace, and unity. Or set by the Character Counts in America such as: trustworthiness, respect, responsibility, fireness, caring, citizenship, honesty, courage, diligence, and integrity (IImi, 2017).

Even as the thought offered by Ari Ginanjar Agustian (Assidiqi, 2015) that every positive character will actually refer to the noble qualities of God, namely al-Asma ${ }^{\prime}$ al-Husnā. The nature and noble names of God are the source of inspiration for every positive character formulated by anyone of the many characters that can be emulated from the names of God, among others, honest, responsible, disciplined, visionary, fair, caring, and collaborating (Pranowo, 2013).

It is clear that the values or characters that must be possessed by students are in harmony with the goals of the Indonesian people as stated in the Law of the Republic of Indonesia No. 20 of 2003 as follows: the nation, which aims to develop the potential of students to become human beings who believe and devote to God the Almighty, noble, healthy, knowledgeable, capable, creative, independent, and become citizens of a democratic and responsible country ".

As well as in line with the formulation of the goal of Islamic education from the world congress that education must be aimed at creating a balanced growth of the human personality as a whole, by training the mind, mind, feelings, and physical human beings. Thus, education must strive for the growth of all human potential, both spiritual, intellectual, imaginary, physical, scientific, and language, both individually and in groups, and encourage the growth of all aspects in order to achieve goodness and perfection. The ultimate goal of education lies in the implementation of full devotion to God the Almighty, both at the level of individuals, groups, and humanity in the broadest sense (Nata, 2010, p. 62).

The figure of Islamic education in the Qur'an is the Prophet Muhammad pbuh (Junaedi, 2017, p. 94). Since the first time he mensyi'arkan Islamic teachings do not deny the planting of noble values that must be owned by students, namely friends. Especially the planting of alAkhlāq al-Karimah. The moral values of students are a reflection of his success in carrying out education. In harmony with the duties of the Prophet pbuh sent by God the Almighty, namely perfecting morals.

Humanizing humanity starts from character habitus and attitude of national cultural character which is actualized in real action through creativity that produces products (Wijaya \& Helaluddin, 2018). Products that are outputs of the intelligence of the existence of human life directed at noble goals. Cultural diversity as a unifying nation through character education fosters a spirit of nationality which encourages the creation of a life that educates the nation. Character education that humanizes humans will produce creativity in reproduction. Talented humans and national character who have the spirit of entrepreneurship, creativity, being able to reproduce will create a society that is advanced, prosperous, and just (Wijaya \& Helaluddin, 2018). 
The aim of the Indonesian gold generation is to achieve a straight path of life that is achieving spiritual intelligence that is optimal in this case is a generation that is able to be grateful in all things. Creativity in producing products and sharing with others and developing appropriate technology, and advanced technology can advance a nation. But now, many things have been achieved, but many also change with the environment, ecosystems, and culture, and human behavior that tends to consumerism that not many care about the environment, and others. Strength in self that is grateful is needed to be able to build a national character that is responsible, and think creatively, and wisely in managing natural resources for the welfare of a just society (Wijaya \& Helaluddin, 2018).

Corruption, moral crisis, and in the name of religion, people, and certain interests have brought this nation down to the dignity of the nation itself. It is the time for the younger generation to think and act that this Indonesian nation must be directed to character education that contains national character, creative, cooperation, tolerance, peace of mind, and upholding the values of national character to realize a smart nation as a whole (Nurfadila, 2018).

Formation of good character in students is not as easy as turning your palm. Students are often influenced by the environment in which they exist. Not all environments have a positive influence on their personal development as well as on character building and the planting of expected religious values. Therefore, there must be guidance with the concept of Islamic education on the environment in question. The environment includes the family environment, school environment, and community environment (Widiani \& Wangidah, 2016).

\section{CONCLUSION}

Character education or character education appears in Indonesia in the midst of the Islamic education system accepted by Muslim communities with characters formulated as reinforcement of Islamic education so that character education is essentially a spirit in Islamic education.

Islamic education has a clear and detailed scope. The scope is a component with each other interrelations, can not be separated so as to form a system. The existence of Islamic education is not only determined well or not one component but all components go in the same direction for the creation of Islamic education anywhere and anytime. Along with the problems of education in general that are never finished

The scope of Islamic education basically refers to sources that are within the Muslim life guidelines, namely Qur'ān, Sunnah, and ljtihād. So that in its presence in the midst of Muslim society can not be separated from the characters or values that exist in the guidelines of the Muslim community. The characters that are expected to have been formulated clearly must be possessed by every student after they take education both in the family environment, school environment, and community environment so that they can further shape their spiritual intelligence..

\section{REFERENCES}

Agustian, A. G. (2002). ESQ Power. Jakarta: Arga. 
Aini, N., Ruslan, R., \& Ely, R. (2013). PENANAMAN NILAI-NILAI MORAL PADA SISWA DI SD NEGERI LAMPEUNEURUT. Jurnal IImiah Mahasiswa Pendidikan Guru Sekolah Dasar, 1(1), 68-77.

Ainissyifa, H. (2014). Pendidikan Karakter dalam Perspektif Pendidikan Islam. Jurnal Pendidikan Universitas Garut, 8(1), 1-26.

Andayani, T. R., Yusuf, M., \& Hardjajani, T. (2011). Development Strategy for Living Values Education Through Learning Model of Tolerance Based on "Tepa Sarira" (An Alternative Character Education). Retrieved from LPPM-UNS website: https://lppm.uns.ac.id/id/2011/01/05/development-strategy-for-living-valueseducation-through-learning-model-of-tolerance-based-on-tepa-sarira-analternative-character-education/

Anees, B. Q., \& Hambali, A. (2010). Pendidikan Karakter Berbasis al-Qur'an. Bandung: Simbiosa Rakatama.

Angeles, P. A. (1981). Dictionary of Philosophy. New York: Barnes \& Noble Books.

Anshori, M. H. (1995). Kamus Psikologi. Surabaya: Usaha Kanisius.

Assidiqi, H. (2015). Membentuk karakter peserta didik melalui model pembelajaran search, solve, create, and share. Math Didactic: Jurnal Pendidikan Matematika, 1(1), 4555. https://doi.org/10.33654/math.v1i1.94

Bali, M. M. (2013). Peran Dosen dalam Mengembangkan Karakter Mahasiswa. Humaniora, 4(2), 800-810. https://doi.org/10.21512/humaniora.v4i2.3508

Darmadi. (2018). KECERDASAN SPIRITUAL. n.p.: Guepedia.

Dasoo, N. (2010). Nurturing Teacher Wellbeing through Values Education. In T. Lovat, R. Toomey, \& N. Clement (Eds.), International Research Handbook on Values Education and Student Wellbeing. New York - Dordrecht: Springer Science \& Business Media.

Fathurrochman, I., \& Apriani, E. (2017). PENDIDIKAN KARAKTER PRESPEKTIF PENDIDIKAN ISLAM DALAM UPAYA DERADIKALISASI PAHAM RADIKAL. POTENSIA: Jurnal Kependidikan Islam, 3(1), 122-142. https://doi.org/10.24014/potensia.v3i1.2726

Frimayanti, A. I. (2015). IMPLEMENTASI PENDIDIKAN NILAI DALAM PENDIDIKAN AGAMA ISLAM. Al-Tadzkiyyah: Jurnal Pendidikan Islam, 6(2), 199-216.

Gil'adi, A. (1992). Children of Islam: Concepts of Childhood in Medieval Muslim Society. Hampshire - London: Springer.

Hadisi, L. (2015). PENDIDIKAN KARAKTER PADA ANAK USIA DINI. Jurnal AI-Ta'dib, 8(2), 50-69. https://doi.org/10.31332/atdb.v8i2.410

IImi, D. (2017). KEWIBAWAAN ( HIGH TOUCH) SEBAGAI MEDIA PENDIDIKAN KARAKTER. ISLAM TRANSFORMATIF : Journal of Islamic Studies, 1(1), 45-54. https://doi.org/10.30983/it.v1i1.329

Irhandayaningsih, A. (2013). PENDIDIKAN KARAKTER DI PERGURUAN TINGGI: MENYIKAPI DEKANDENSI MORAL DI KALANGAN GENERASI MUDA. HUMANIKA, 17(1), 125-138.

Junaedi, M. (2017). Paradigma Baru Filsafat Pendidikan Islam. Jakarta: Kencana.

Majid, A., \& Andayani, D. (2012). Jual Pendidikan Karakter Perspektif Islam. Retrieved from https://www.tokopedia.com/bastcampbuku/pendidikan-karakter-perspektifislam-abdul-majid-dian-andayani-1

Manasikana, A., \& Anggraeni, C. W. (2018). PENDIDIKAN KARAKTER DAN MUTU PENDIDIKAN INDONESIA. Retrieved from 
https://publikasiilmiah.ums.ac.id/bitstream/handle/11617/10206/Makalah\%2013\%2 OArina\% 20Manasikana.pdf?sequence=1\&isAllowed=y

McKay, L. (2009). Mobilizing for Evidence-Based Character Education. Washington DC:

DIANE Publishing.

Muhdar HM. (2013). Pendidikan Karakter Menuju SDM Paripurna. Al-Ulum, 13(1), 103128.

Muin, F. (2011). Pendidikan Karakter : Konstruksi Teoritik dan Praktik. Retrieved from http://opac.lib.ugm.ac.id/index.php?mod=book_detail\&sub=BookDetail\&act=view\&t yp=htmlext\&buku_id=468263\&obyek_id=1

Mujib, A., \& Mudzakir, Y. (2002). Nuansa-Nuansa Psikologi Islam. Jakarta: Raja Grafindo Persada.

Mujib, A., \& Mudzakir, Y. (2006). IImu Pendidikan Islam. Jakarta: Prenada Media.

Musfiroh, M., \& Setiawan, A. R. (2019). Pendidikan Karakter: Akhlak, Adab, Moral dan Nilai. INA-Rxiv. https://doi.org/10.31227/osf.io/x8syc

Nata, A. (1996). Akhlak tasawuf. Jakarta: Rajagrafindo Persada.

Nata, A. (2010). IImu Pendidikan Islam. Kencana.

Nucci, L., Narvaez, D., \& Krettenauer, T. (2014). Handbook of Moral and Character Education. New York: Routledge.

Nurdin, C. (2017). Perbedaan; Pendidikan Karakter, Moral dan Akhlak. Retrieved from https://geotimes.co.id/opini/perbedaan-pendidikan-karakter-moral-dan-akhlak/

Nurfadila, A. (2018, October 16). Krisis Moral Bangsa Indonesia. Retrieved from https://www.kompasiana.com/aulian/5bc5a03e6ddcae27482ee384/krisis-moralbangsa-indonesia?page=all

Omeri, N. (2015). PENTINGNYA PENDIDIKAN KARAKTER DALAM DUNIA PENDIDIKAN. MANAJER PENDIDIKAN, 9(3), 464-468.

Parens, J. (2012). Islamic Philosophy of Virtuous Religions, An: Introducing Alfarabi. New York: SUNY Press.

Pesci, F. (2018). The Family and Affective Education. In J. Tham (Ed.), Sexuality, Gender \& Education. Roma: IF Press.

Pranowo, D. J. (2013). IMPLEMENTASI PENDIDIKAN KARAKTER KEPEDULIAN DAN KERJA SAMA PADA MATA KULIAH KETERAMPILAN BERBICARA BAHASA PRANCIS DENGAN METODE BERMAIN PERAN. Jurnal Pendidikan Karakter, 2(2), 218-230. https://doi.org/10.21831/jpk.v2i2.1442

Rahim, A. (2013). Peranan Orang Tua terhadap Pendidikan Karakter Remaja Putri menurut Islam. Al-Ulum, 13(1), 87-102.

Ramaliyus. (2010). IImu Pendidikan Islam. Jakarta: Kalam Mulia.

Reksiana. (2018). KERANCUAN ISTILAH KARAKTER, AKHLAK, MORAL DAN ETIKA. THAQAFIYYAT: Jurnal Bahasa, Peradaban dan Informasi Islam, 19(1), 1-30.

Samrin. (2016). PENDIDIKAN KARAKTER (SEBUAH PENDEKATAN NILAI) | Samrin | AlTA'DIB. Jurnal Al-Ta'dib, 9(1), 120-143. https://doi.org/10.31332/atdb.v9i1.505

Sanderse, W. (2012). Character Education. Delft: Eburon Uitgeverij B.V.

Syam, J. (2016). Pendidikan Berbasis Islam yang Memandirikan dan Mendewasakan. EduTech: Jurnal IImu Pendidikan Dan IImu Sosial, 2(2), 73-83.

Syarif, M. (2017). Pelaksanaan Pendidikan Karakter dalam Pembelajaran PAI di SMK Hasanah Pekanbaru. Jurnal Pendidikan Agama Islam Al-Thariqah, 1(1), 27-40. https://doi.org/10.25299/althariqah.2016.vol1(1).616

Tafsir, A. (2013). IImu Pendidikan Islam. Bandung: Remaja Rosdakarya. 
Tulus, M. (2013). KONFIGURASI PENDIDIKAN KARAKTER BERPARADIGMA KEBANGSAAN; USAHA MENEGUHKAN IDENTITAS DIRI BANGSA DARI KUNGKUNGAN ARUS GLOBALISASI. El-Hikmah, IX(2), 257-279.

Verger, A., \& Novelli, M. (2012). Campaigning for "Education for all": Histories, Strategies and Outcomes of Transnational Advocacy Coalitions in Education. Rotterdam Boston - taipei: Springer Science \& Business Media.

Widiani, D., \& Wangidah, S. (2016). Pendidikan Karakter bagi Anak Autis di Sekolah Khusus Taruna al-Qur'an yogyakarta. JURNAL PENELITIAN, 10(1), 1-24. https://doi.org/10.21043/jupe.v10i1.1365

Wijaya, H., \& Helaluddin, H. (2018, February 23). Hakikat Pendidikan Karakter. Retrieved from https://www.researchgate.net/publication/323364661_Hakikat_Pendidikan_Karakt er

Zohar, D., \& Marshall, I. (2007). SQ - Kecerdasan Spiritual. Bandung: Mizan Pustaka. 